\title{
Grazing system and floor type effects on blood biochemistry, growth and carcass characteristics of Nguni goats
}

\author{
Allen Tapiwa Chikwanda ${ }^{1,2}$ and Voster Muchenje ${ }^{1, *}$
}

* Corresponding Author: Voster Muchenje Tel: +27-406022059, Fax: +27-086-628-2967,

E-mail: vmuchenje@ufh.ac.za

' Department of Livestock and Pasture Science, Faculty of Science and Agriculture, University of Fort Hare, P. Bag X1314, Alice 5700, South Africa

${ }^{2}$ Animal Science Department, Faculty of Agriculture

and Environmental Sciences, Bindura University of

Science Education, No. 741 Chimurenga Road P Bag

1020, Bindura 0271, Zimbabwe

Submitted Apr 28, 2016; Revised Jun 19, 2016; Accepted Dec 10, 2016
Objective: Purpose was to determine the effects of grazing system and floor type on concentrations of blood metabolites, activity of creatine kinase, body weight and carcass characteristics of castrated Nguni goats.

Methods: Forty eight, 7 month old goats were randomly allocated to herding and tethering treatments from 0800 to 1300 hours and accommodated on slatted and earth floors daily. Blood samples were collected by jugular venipuncture every fifteenth day for metabolite analysis. Slaughter was done at a commercial abattoir following 5 months of monitoring.

Results: Tethered goats had significantly higher concentrations of urea $(5.19 \mathrm{mmol} / \mathrm{L})(\mathrm{p}<$ $0.001)$, creatinine $(55.87 \mu \mathrm{mol} / \mathrm{L})(\mathrm{p}<0.05)$, total protein $(64.60 \mathrm{~g} / \mathrm{L})(\mathrm{p}<0.01)$, and globulin $(49.79 \mathrm{~g} / \mathrm{L})(\mathrm{p}<0.001)$, whereas herded goats had higher glucose $(3.38 \mathrm{mmol} / \mathrm{L})(\mathrm{p}<0.001)$, albumin $(15.33 \mathrm{~g} / \mathrm{L})(\mathrm{p}<0.05)$, albumin/globulin ratio $(0.34)(\mathrm{p}<0.01)$, and body weight $(24.87 \mathrm{~kg})(\mathrm{p}<$ $0.001)$. Slatted floors caused higher $(\mathrm{p}<0.01)$ albumin at $15.37 \mathrm{~g} / \mathrm{L}$. The interaction of grazing system and floor type affected creatinine, total protein, globulin at $(\mathrm{p}<0.01)$ and albumen/globulin ratio at $(p<0.01)$. The least creatinine concentration and albumin/globulin ratio was in herded and tethered goats that were accommodated on earth floors, respectively. The highest total protein and globulin concentrations were in serum of tethered goats that were accommodated on earth floors. The highest $(\mathrm{p}<0.05)$ dressing percentage $(45.26 \%)$ was in herded goats accommodated on slatted floors.

Conclusion: Herding of goats lowered globulin concentration, improved estimated feed intake, blood glucose and albumin concentrations, albumin globulin ratio, increased body weights and weight related carcass characteristics. Floor type had very little effects on metabolites where earth floors only reduced albumin concentration. Tethering and housing goats on earth floors resulted in double stress that increased chronic infections.

Keywords: Blood Biochemistry; Floor Type; Grazing System; Goat

\section{INTRODUCTION}

It is commaon practice among smallholder farmers under the crop-livestock farming systems to tether or herd goats [1]. The grazing systems are mainly done to prevent goats from damaging crops or grain in storage. The goats are allowed to forage for a few hours and are then penned in facilities with different floor types, for extended periods of time per day. Tethering or herding of goats cause different restrictions on foraging mobility as permitted by length of rope and extent to which they access forages and possibly satisfaction of nutritional requirements. Floor types influence the comfort and rest of goats during penning. Some goat facilities become muddy and force the goats to spend whole nights standing. The lack of rest by such goats causes fatigue which compromises their ability to forage when they are finally released, for feeding, the following day. Damp floor conditions affect feet condition and make them susceptible to foot rot [2] which further impairs foraging ability. The welfare of goats under these grazing systems and floor types 
needs attention and their nutritional status needs evaluation. Nutritional adequacy to the goats can be evaluated using blood metabolites, daily weight gains, body condition scores (BCS) [3] and carcass characteristics.

Inadequate nourishment triggers mobilisation of body reserves, loss of weight, and BCS [4]. Blood metabolites are important indicators of nutritional status that change profile even before alterations in body weights are observed [5]. Blood biochemistry gives a reliable and consolidated measure of the sufficiency of dietary nutrients that can be used regardless of the physiological state of the animal [6]. Metabolites that reflect an animal's protein status include: albumin, globulin, total protein (TP), creatinine, and urea [3]. Albumin concentration decreases when an animal is exposed to deficiencies in dietary protein or parasitism $[7,8]$. Compromised nourishment leads to the mobilisation of muscle which is shown by reduced body condition, loss of weight, an increase in blood urea [4] and low creatinine concentration. On the other hand, negative energy balance leads to lipid metabolism that results in elevated concentrations of non-esterified fatty acids and $\beta$-hydroxybutyrate [3].

This study was done in order to establish the effect of tethering, herding and floor type on blood profiles, growth performance and carcass characteristics of Nguni goats. To our knowledge, there is limited information on nutrient status and carcass characteristics of tethered and herded goats that are accommodated in pens with earth or slatted floors. The results of the study were expected to give recommendations as to the goat grazing system and floor type that would lead to adequate nutrient uptake as indicated by better concentrations of blood metabolites, growth and BCS.

\section{MATERIALS AND METHODS}

The procedures used on the goats were approved by the University of Fort Hare's Research Ethics Committee (UREC) and accorded ethical certificate reference number: MUC101SCHI01.

\section{Location of study}

The study was performed at the University of Fort Hare, Honeydale Research Farm located on Global Positioning System coordinates $32^{\circ} 46^{\prime} \mathrm{S}$ and $26^{\circ} 51^{\prime} \mathrm{E}$ at $520 \mathrm{~m}$ above sea level, Republic of South Africa. The area receives mean annual precipitation of $490 \mathrm{~mm}$. The vegetation has browse species such as: Grewia occidentalis, Scurtia myrtina, Scutia indica, Rhus longispina, Olea africana, Ehretia rigida, and Acacia karroo. In addition, grasses such as: Panicum maximum, Digitaria eriantha, Pennisetum clandestinum, Eragrostis spp, Themeda triandra, and Cynodon dactylon are available in the area [9].

\section{Animal management}

The study was a $2 \times 2$ factorial arrangement of treatments in a completely randomised design. The two factors were grazing sys- tem (tethering vs herding) and house floor type (earth vs slatted). Each grazing system was randomly assigned 3 pens per floor type and each pen accommodated 4 goats.

Forty eight clinically healthy Nguni goats were used in this study. The goats were given prophylactic treatment of antibiotic (HI- TET 200 LA Gold, Bayer Animal Health Proprietary Limited, Isando, South Africa), spray dipped against ectoparasites, dewormed and acclimatised to the treatments for 14 days. Twenty four of the Nguni goats were tethered and the remaining 24 were guided, by shepherds, to forage within the vicinity of the tethered goats. The goats were let out from pens for foraging at 0800 hours and re- penned at $1300 \mathrm{hrs}$ daily for five months. Tethered goats were individually tied by $3 \mathrm{~m}$ ropes to browse trees. The tethering spots were changed at frequencies of 3 to 4 times every 5 hours of foraging time. Feed intake was estimated from body weights and average daily gain (ADG) using [10] guidelines. The [10] feed intake tables show the estimated dry matter (DM) intake, TP, total digestible nutrients (TDN), calcium (Ca), phosphorus (P), Vitamin A, and Vitamin D that are required for maintenance and growth per given body weights and average daily weight gain. The herded goats had unrestricted access to water troughs in the foraging site. The tethered and herded goats were allowed access to water prior to being penned. Ten millilitres of blood were collected per goat, twice a month, for 5 months. At the completion of the study the goats were slaughtered at a commercial abattoir according to their procedures.

\section{Blood biochemical study}

Blood samples were collected from all goats by jugular venipuncture into two $5 \mathrm{~mL}$ vacutainer tubes for separation of plasma (grey top vacutainer tubes impregnated with anticoagulant ethylene diamine tetra acetic acid, and sodium fluoride to arrest glycolysis) and serum (gold top vacutainer tubes with clot activator and gel). The blood in the vacutainer tubes was then centrifuged at 3,500 rounds per minute (rpm), at a temperature of $10^{\circ} \mathrm{C}$ for 15 minutes (Model 5403 centrifuge, Gatenbay Eppendorf GmbH, Engelsdorp, Leipzig, Germany) in order to separate the plasma and serum. The plasma and serum was then transferred to $1.8 \mathrm{~mL}$ cryovials and stored at $-20^{\circ} \mathrm{C}$ pending analysis. Glucose was estimated in the plasma using enzymatic methods [11] in which NAE2-27 reagent was used following oxidation with glucose oxidase. A Chexcks machine (Next/Vetex Alfa Wasseman Analyser, Woerden, Netherlands) and commercially available kits (Siemens Proprietary Limited, Midrand, South Africa) were used to analyse serum. Serum was analysed spectrophotometrically for creatinine [12] TP and albumin $[13,14]$ using colorimetric methods. Urea analysis was done using enzymatic methods [12]. Globulin concentration was computed by subtracting albumin concentration from TP, whereas albumin- globulin ratio was calculated by dividing albumin concentration by that of globulin. Ultra violet methods were used to determine activity of creatine kinase (CK) [15]. 


\section{Growth and body condition scoring}

Body weights were recorded on a salter suspended weighing machine (model 235) at every 15 days before foraging. Body condition scoring was done on a five point scale (range 1 to 5) [16] with intermediate 0.5 units. Briefly, muscle and fat cover around the lumbar vertebrae, the amount of fat around the sternum were assessed by feeling the quantity of fat that could be pinched and the fat covering the ribs and intercostal muscle jointly gave the overall BCS [16].

\section{Goat slaughter}

All goats were slaughtered in a commercial abattoir after a $24 \mathrm{~h}$ fast with ad libitum access to water. Electro stunning was done at $650 \mathrm{~V}$ for five seconds just before slaughter. Sticking was then done and the carcass hung by the hind leg on an overhead pulley and bled for 6 minutes. This was followed by skinning and evisceration. The hot carcass weight (HCW) was the weight after removal of head; abdominal viscera and internal organs; skin; hind feet (at tarsal- metatarsal joint) and front feet (at carpalmetacarpal joint) [17]. Cold carcass weight (CCW) was the weight of the carcass after conditioning at $2^{\circ} \mathrm{C}$ to $4^{\circ} \mathrm{C}$ for 24 hours. The dressing percentage (DP) was computed as the ratio of $\mathrm{HCW}$ to body weight before slaughter (WBS) expressed as a percentage [i.e. $(\mathrm{HCW}) /(\mathrm{WBS}) \times 100]$. The chilling loss $(\%)$ was calculated as $([\mathrm{HCW}-\mathrm{CCW}] /[\mathrm{HCW}] \times 100)[17]$. Carcass grading and classification was done by a trained and certified meat grader.

\section{Statistical analysis}

The effects of grazing system (tethering versus herding), floor type (earth floor versus slatted floor) on blood metabolites, live weights and BCS of Nguni goats were analysed using the general linear models procedure of [18]. Significant differences between means were compared using Tukey's Studentized Range test. The Chi- square test was used to test for relationship between the grazing system and: age, fat and conformation class. Pearson's correlation coefficient among blood metabolites, live weight and BCS were determined using [18]. The following statistical

Table 1. Means of blood chemistry parameters of Nguni goats reared under tethering and herding grazing systems

\begin{tabular}{lccc}
\hline Parameter & \multicolumn{2}{c}{ Grazing system } & \multirow{2}{*}{$\begin{array}{c}\text { Significance } \\
\text { level }\end{array}$} \\
\cline { 2 - 3 } & $\mathbf{H}$ & $\mathbf{T}$ & $* * *$ \\
\hline Glucose $(\mathrm{mmol} / \mathrm{L})$ & 3.38 & 3.24 & $* * *$ \\
Urea $(\mathrm{mmo} / \mathrm{L})$ & 4.61 & 5.19 & $*$ \\
Creatinine $(\mu \mathrm{mol} / \mathrm{L})$ & 54.15 & 55.87 & $* *$ \\
Total protein $(\mathrm{g} / \mathrm{L})$ & 62.35 & 64.60 & $*$ \\
Albumin $(\mathrm{g} / \mathrm{L})$ & 15.33 & 14.80 & $* * *$ \\
Globulin $(\mathrm{g} / \mathrm{L})$ & 47.01 & 49.79 & $* *$ \\
Albumin/globulin ratio & 0.34 & 0.30 & $\mathrm{NS}$ \\
Creatine Kinase $(\mathrm{U} / \mathrm{L})$ & 197.97 & 203.29 &
\end{tabular}

$T$, tethering grazing system; $H$, herding grazing system; NS, no significant difference.

${ }^{*} p<0.05 ;{ }^{* *} p<0.01 ;{ }^{* *} p<0.001$. model was used:

$$
\begin{aligned}
\mathrm{Y}_{\mathrm{ijk} \mathrm{kl}}= & \mu+\mathrm{G}_{\mathrm{i}}+\mathrm{H}_{\mathrm{j}}+\mathrm{W}_{\mathrm{k}}+(\mathrm{G} \times \mathrm{H})_{\mathrm{ij}}+(\mathrm{G} \times \mathrm{W})_{\mathrm{ik}} \\
& +(\mathrm{H} \times \mathrm{W})_{\mathrm{jk}}+(\mathrm{G} \times \mathrm{H} \times \mathrm{W})_{\mathrm{ijk}}+\mathrm{e}_{\mathrm{ijk} \mathrm{k}}
\end{aligned}
$$

Where, $\mathrm{Y}_{\mathrm{i} \mid \mathrm{kl}}=$ Is the response variable (e.g. metabolite: glucose, urea); $\mu$ = population mean; $G_{i}=$ effects of grazing system ( $i=1$, $2) ; F_{j}=$ effect due to floor type $(j=1,2) ; W_{k}=$ effects of due to week of collection $\left(j=1,2, \ldots 20\right.$ weeks); $(G \times F)_{i j}=$ effects due to interaction of grazing system and floor type, $(\mathrm{G} \times \mathrm{W})_{\mathrm{ik}}=$ effects due to interaction of grazing system by week; $\mathrm{e}_{\mathrm{ijk} k \mathrm{l}}=$ random residual error distributed as $\sim \mathrm{N}\left(0 ; \mathrm{I} \delta \mathrm{e}^{2}\right)$.

\section{RESULTS}

\section{Blood metabolites}

Herding grazing system caused significantly higher concentrations of: glucose $(\mathrm{p}<0.001)$, albumin $(\mathrm{p}<0.05)$ and albumin/globulin ratio $(\mathrm{p}<0.01)$ than tethering (Table 1). On the other hand, tethered goats had significantly higher concentrations of urea, globulin at $(\mathrm{p}<0.001)$, creatinine $(\mathrm{p}<0.05)$, and TP $(\mathrm{p}<0.01)$. Both grazing systems had similar activity of CK. Floor type only affected albumin concentration where the metabolite was significantly higher $(\mathrm{p}<0.01)$ for goats on slatted floors than earth floors (Table 2). There were significant interactions between grazing system and floor type on concentrations of creatinine, globulin, TP at $(\mathrm{p}<0.01)$ and albumin/globulin ratio $(\mathrm{p}<0.05)$ (Table 3$)$.

Body condition scores, body weights and estimated intake There were no significant effects ( $\mathrm{p}>0.05$ ) of floor type on bodyweight, ADG, or BCS (Table 4). Herding grazing system had significantly higher body weights $(\mathrm{p}<0.001)$ (Table 5$)$. However, ADG and BCS were similar ( $>0.05)$ between the two grazing systems. In addition, there were no significant interaction effects ( $>>0.05)$ of grazing system and floor type on body weight or BCS. Herding grazing system had higher estimated DM ( $\mathrm{kg} / \mathrm{head})$, TDN (kg), Vitamin A (IU), Vitamin D (IU) at ( $<<0.01)$; TP (kg),

Table 2. Means of blood chemistry parameters of Nguni goats accommodated in earth floors and slatted floors

\begin{tabular}{lccc}
\hline \multirow{2}{*}{ Parameter } & \multicolumn{2}{c}{ Floor type } & Significance \\
\cline { 2 - 3 } & E & S & level \\
\hline Glucose $(\mathrm{mmol} / \mathrm{L})$ & 3.29 & 3.33 & NS \\
Urea $(\mathrm{mmol} / \mathrm{L})$ & 4.85 & 4.95 & $\mathrm{NS}$ \\
Creatinine $(\mu \mathrm{mol} / \mathrm{L})$ & 54.74 & 55.34 & $\mathrm{NS}$ \\
Total protein $(\mathrm{g} / \mathrm{L})$ & 63.86 & 63.09 & $\mathrm{NS}$ \\
Albumin $(\mathrm{g} / \mathrm{L})$ & 14.78 & 15.37 & $* *$ \\
Globulin $(\mathrm{g} / \mathrm{L})$ & 49.09 & 47.72 & $\mathrm{NS}$ \\
Albumin/globulin ratio & 0.32 & 0.33 & $\mathrm{NS}$ \\
Creatine Kinase $(\mathrm{U} / \mathrm{L})$ & 205.20 & 195.69 & $\mathrm{NS}$ \\
\hline
\end{tabular}

$\mathrm{E}$, earth floors; $\mathrm{S}$, slatted floors; NS, no significant difference.

${ }^{*} p<0.05 ;{ }^{* *} p<0.01 ;{ }^{* *} p<0.001$. 
Table 3. Means of blood chemistry parameters of tethered and herded Nguni goats accommodated in earth floors and slatted floors

\begin{tabular}{lccccc}
\hline \multirow{2}{*}{ Parameter } & \multicolumn{4}{c}{ Treatment } & $\begin{array}{c}\text { Significance } \\
\text { level }\end{array}$ \\
\cline { 2 - 5 } & HE & HS & TE & TS & NS \\
\hline Glucose (mmol/L) & $3.35^{\mathrm{c}}$ & $3.43^{\mathrm{c}}$ & $3.22^{\mathrm{a}}$ & $3.23^{\mathrm{a}}$ & NS \\
Urea (mmol/L) & $4.56^{\mathrm{a}}$ & $4.66^{\mathrm{a}}$ & $5.08^{\mathrm{b}}$ & $5.14^{\mathrm{b}}$ & $* *$ \\
Creatinine $(\mu \mathrm{mol} / \mathrm{L})$ & $52.59^{\mathrm{a}}$ & $56.23^{\mathrm{b}}$ & $57.53^{\mathrm{b}}$ & $55.35^{\mathrm{b}}$ & $* *$ \\
Total protein $(\mathrm{g} / \mathrm{L})$ & $61.51^{\mathrm{a}}$ & $62.84^{\mathrm{a}}$ & $66.20^{\mathrm{b}}$ & $63.16^{\mathrm{a}}$ & $* *$ \\
Albumin $(\mathrm{g} / \mathrm{L})$ & $15.11^{\mathrm{b}}$ & $15.48^{\mathrm{b}}$ & $14.42^{\mathrm{a}}$ & $15.24^{\mathrm{b}}$ & $\mathrm{NS}$ \\
Globulin (g/L) & $46.37^{\mathrm{a}}$ & $47.37^{\mathrm{a}}$ & $51.76^{\mathrm{b}}$ & $47.93^{\mathrm{a}}$ & $* *$ \\
Albumin/globulin ratio & $0.36^{\mathrm{b}}$ & $0.33^{\mathrm{b}}$ & $0.29^{\mathrm{a}}$ & $0.32^{\mathrm{b}}$ & $*$ \\
Creatine Kinase (U/L) & $207^{\mathrm{a}}$ & $184^{\mathrm{a}}$ & $198.89^{\mathrm{a}}$ & $205.28^{\mathrm{a}}$ & NS \\
\hline
\end{tabular}

$\mathrm{HE}$, herded goats accommodated on earth floors; $\mathrm{HS}$, herded goats accommodated on slatted floors; TE, tethered goats accommodated on earth floors; TS, tethered goats accommodated on slatted floors; NS, no significant difference.

Means with different superscripts within the same row were significantly different. ${ }^{*} p<0.05 ;{ }^{* *} p<0.01 ;{ }^{* * *} p<0.001$

Table 4. Means of body weight, average daily gain and body condition score of goats accommodated on earth or slatted floors

\begin{tabular}{|c|c|c|c|}
\hline \multirow{2}{*}{ Parameter } & \multicolumn{2}{|c|}{ Floor type } & \multirow{2}{*}{$\begin{array}{c}\text { Significance } \\
\text { level }\end{array}$} \\
\hline & $\mathrm{E}$ & $S$ & \\
\hline Body weight (kg) & 23.71 & 23.57 & NS \\
\hline Average daily gain $(\mathrm{kg})$ & 0.044 & 0.039 & NS \\
\hline$B\left(S^{1)}\right.$ & 3.20 & 3.32 & NS \\
\hline
\end{tabular}

E, earth floor; S, slatted floor; NS, no significant difference; BCS, body condition scores.

1) BCS on a point scale 1 to 5 .

$\mathrm{Ca}(\mathrm{kg}), \mathrm{P}(\mathrm{kg})(\mathrm{p}<0.001)$ intake compared to tethering (Table 5).

\section{Carcass characteristics}

Herding management system had significantly higher slaughter weight $(\mathrm{p}<0.05)$; warm weight $(\mathrm{p}<0.01)$, CCW $(\mathrm{p}<0.01)$, and DP $(p<0.01)$ than tethering system (Table 6$)$. Chilling loss was not affected $(\mathrm{p}>0.05)$ by grazing system. There was significant interaction effect of grazing system and floor type on DP $(\mathrm{p}<0.05)$. The DP was $45.26 \%$ and $41.14 \%$ for herded and tethered goats accommodated on slatted floors, respectively. On the other hand, DP was $42.08 \%$ and $41.34 \%$ for herded and tethered goats on earth floors, respectively. There was no relationship between grazing system and; age, fat nor confirmation as shown by the low Chi- square values (Table 7).
Table 6. Means of carcass characteristics of tethered and herded Nguni goats

\begin{tabular}{lccc}
\hline \multirow{2}{*}{ Parameter } & \multicolumn{2}{c}{ Grazing system } & $\begin{array}{c}\text { Significance } \\
\text { level }\end{array}$ \\
\cline { 2 - 3 } & H & T & $*$ \\
Slaughter weight $(\mathrm{kg})$ & 28.68 & 25.11 & $*$ \\
Warm weight $(\mathrm{kg})$ & 12.60 & 10.38 & $*$ \\
Cold carcass weight $(\mathrm{kg})$ & 12.23 & 10.07 & $*$ \\
Chilling loss (\%) & 2.98 & 3.02 & NS \\
Dressing percentage (\%) & 43.67 & 41.24 & $* *$ \\
\hline
\end{tabular}

$H$, herded; T, tethered; NS, no significant difference.

${ }^{*} p<0.05 ;{ }^{* *} p<0.01$.

\section{DISCUSSION}

\section{Blood metabolites}

The activity of CK was similar for both grazing systems and floor types but much higher compared to the normal expected 0.8 to 8.9 U/L range for healthy goats [19]. High activity of CK is an indication of release of the enzyme into the blood following muscle damage $[20,21]$ such as when goats engage in fights or bump against objects in their random motions. The goats in the current study were very agile when driven to and from foraging areas which could have elevated the activity of CK. The enzyme CK is responsible for maintaining energy homeostasis in skeletal muscles that use high adenosine triphosphate, such as muscles for locomotion on limbs [22]. Restriction of goat movement by tethering or differences in floor type was, therefore, insufficient to bring down the activity of CK from the threshold attained in moving to or from the foraging areas.

Table 7. Chi- square test of independence between grazing system and: age, fat and conformation class

\begin{tabular}{|c|c|c|c|c|c|}
\hline \multirow{2}{*}{ Parameter ${ }^{1)}$} & \multicolumn{2}{|c|}{ Grazing system } & \multirow{2}{*}{ DF } & \multirow{2}{*}{$\begin{array}{l}\text { Chi-square } \\
\text { value }\end{array}$} & \multirow{2}{*}{$p$ value } \\
\hline & $\mathrm{H}$ & $T$ & & & \\
\hline Age class: A (\%) & 32.61 & 34.78 & 1 & 0.10 & 0.753 \\
\hline Age class: AB (\%) & 17.39 & 15.22 & & & \\
\hline Fat class $0(\%)$ & 39.13 & 47.83 & 1 & 3.07 & 0.080 \\
\hline Fat class $1(\%)$ & 10.87 & 2.17 & & & \\
\hline Conformation class $1(\%)$ & 2.17 & 8.70 & 1 & 2.02 & 0.160 \\
\hline Conformation class 2 (\%) & 47.83 & 41.30 & & & \\
\hline
\end{tabular}

$\mathrm{H}$, herding grazing system; T, tethering grazing system; DF, Degrees of freedom. 1) Age class: $A$, no permanent incisors; Age class: $A B$, at least one but not more than two permanent incisors [27]; Fat class: 0, no fat; Fat class: 1, very lean [27]; Conformation class: 1, very flat; Conformation class: 2, flat [27].

Table 5. Body weights, average daily gains, body condition scores and estimated intake requirements for maintenance and growth of tethered and herded goats ${ }^{1)}$

\begin{tabular}{lccccccccccc}
\hline GS & BW $(\mathbf{k g})$ & ADG (kg) & BCS & DM kg/head & $\%$ BW & TP (kg) & TDN (kg) & Ca (kg) & P (kg) & Vit. A (IU) & Vit. D (IU) \\
\hline H & 24.87 & 0.049 & 3.27 & 0.778 & 2.315 & 0.059 & 0.427 & 0.042 & 0.0017 & $1,108.14$ & 230.31 \\
T & 22.47 & 0.035 & 3.24 & 0.713 & 2.353 & 0.053 & 0.392 & 0.002 & 0.0015 & $1,016.43$ & 210.99 \\
Significant difference & $* * *$ & NS & NS & $* *$ & $* *$ & $* * *$ & $* *$ & $* * *$ & $* * *$ & $* *$ & $* *$ \\
\hline
\end{tabular}

GS, grazing system; BW, body weight; DM, dry matter; TP, total protein; TDN, total digestible nutrients; Ca, calcium; P, phosphorus; Vit., vitamin; T, tethering grazing system; H, herding grazing system; NS, no significant difference.

${ }^{*} p<0.05 ;{ }^{* *} p<0.01 ;{ }^{* * *} p<0.001$.

1) Estimates on intake and nutrient requirements for maintenance and additional growth were calculated based on [10] guidelines for observed body weights and average daily gains. 
Serum urea in tethered goats was higher than that obtained in the herding grazing system. However, the urea concentration obtained for both grazing systems was within the normal range of 3.57 to $7.14 \mathrm{mmol} / \mathrm{L}$ found in blood of healthy goats [19]. The normal concentration of serum urea that was observed in the current study for the two grazing systems suggests the possibility of sufficient feed intake. Dry matter feed intake in the current study was normal at approximately 2.3 percent of body weight. The higher urea in tethered goats indicates that herded goats had better nutrient flow especially energy [6]. However, the observed low albumin concentrations make it difficult to make concrete assertions about the adequacy of dietary protein as it reflects either protein undernutrition or parasitism [8]. Possibility of internal parasites can be eliminated due to the regular drenching with deworming remedies that was done in the current study. Rumosa Gwaze et al [23] warned that evaluation of protein intake from urea results alone can be deceptive. Two processes can result in elevated urea concentration. High urea can be due to overproduction of rumen ammonia when ruminants are over fed or from deficiencies in dietary protein that trigger muscle catabolism and concomitant increase in urea. It appears, the higher urea in the tethered goats compared to those that were herded might be a result of increased production of rumen ammonia [23] from the degradation of ingested acacia leaves as the goats were largely tied to the thorny bushes. Herded goats that had lower serum urea were able to select different forage species, had higher DM intake, TP, TDN, and were more efficient in nitrogen utilisation [24]. This was affirmed by the heavier body weights observed in herded goats than tethered goats. The within normal range of urea concentration, obtained for both grazing systems was attributed to possible increase in by- pass protein, due to likely influence of tannin containing browse species, which make the protein evade rumen degradation (i.e. avoid conversion to ammonia a precursor of urea) to be hydrolysed in the abomasum to amino acids.

The mean glucose concentration for herding, tethering and floor type treatments was within the normal range for goats of 2.78 to $4.16 \mathrm{mmols} / \mathrm{L}$ [19]. The observation confirms that there was adequate glucose for life processes at cell level in herded and tethered goats [3]. The glucose was more available in herded goats which were better able to forage freely and selected younger herbage material across the spatially distributed plants and obtained digestible by-pass carbohydrates that were broken down to glucose. Inadequate nutrient uptake or poor feed quality depresses circulatory glucose concentration $[4,7]$. The observed negative correlation between glucose and urea concentration, reflects that there is very little or no conversion of ingested protein to glucose [25]. The glucose concentration obtained in the current study is similar to the findings of [26] in Kiko goats but higher than those obtained by [23] in Nguni goats. Floor type did not influence the circulating concentrations of glucose as they were similar for earth and slatted floors.
The observed mean creatinine concentration for herded and tethered goats was below the normal expected range of 88.40 to $159 \mu \mathrm{mol} / \mathrm{L}$ [19]. The low creatinine concentration confirms that goats had lean muscle [3]. The observed flat to very flat conformation of carcasses [27] of goats under both grazing systems demonstrates the leanness of muscle. Creatinine is a product of breakdown of creatine phosphate in muscle and is expected to be high in larger or older animals that have more skeletal muscle $[3,8]$ reinforcing the view that excretion of creatinine is closely related to muscle mass and is high in bigger animals. The goats that were used in the current study were young with the majority of them having no permanent incisors [27] and, therefore, associated with low levels of creatinine [23]. The observation of higher creatinine in tethered goats, which had lower body weights than herded goats, was perplexing. Creatinine concentration was similar between the floor types. The observation of least creatinine concentration in herded goats on earth floors suggest little breakdown of creatine phosphate in their muscle [8].

Tethered goats had higher TP and globulin concentration compared to herded goats. The total serum protein concentration for tethering treatment group was within the expected normal range of 64 to $70 \mathrm{~g} / \mathrm{L}$ of healthy goats [19], whilst that for herded goats was slightly lower than the optimum range. Plasma protein concentration is normally maintained at optimum concentration and only falls when the dietary protein is low [6]. Tethered goats were thought to have been better able to ingest dietary protein from the bushes that they were tied to. However, the estimated TP intake [10] for tethered goats was lower than the value obtained for their herded counterparts. The observed higher globulin in tethered goats suggests some chronic infections or inflammatory response [7]. Chronic health challenges were attributed to either reinfection at tethering site or stress induced compromised immunity.

The serum albumin concentration obtained for the herding tethering and floor type treatments were far below the expected normal range of 27 to $39 \mathrm{~g} / \mathrm{L}$ for healthy goats [19] and that obtained by other scientists [26]. Low albumin concentration is usually ascribed to protein deficiency and parasitism [7]. However, goats in the current study were routinely dewormed suggesting that dietary protein was limiting. Olafadehan and Mapiye et al $[5,8]$ found a low albumin value of $28.03 \mathrm{~g} / \mathrm{L}$ in goats fed grass with low protein (9.2\% on DM basis) compared to $34.80 \mathrm{~g} / \mathrm{L}$ in those offered a denser protein ( $16 \%$ on DM basis) browse species. In the current study, positive correlation $(\mathrm{r}=0.20)$ was obtained between albumin and BCS. Positive correlations between albumin and optimum nutritional conditions as well as body condition have been reported in other studies [3]. The higher albumin concentration in goats that were herded explains the heavier body weights obtained in that grazing treatment. Solaiman et al [26] highlighted that albumin, in addition to being an indicator of nutritional status, was also a pointer of animal health status where albumin concentration decreased when an animal fell sick. Albu- 
min concentration of goats on slatted floors was higher than of those on earth floors. The observation suggests better welfare and health status of goats on slatted floors. The finding of below normal ranges of albumin, in the current study, suggest compromised nutritional protein and or immune status of the goats under the grazing and floor type treatments.

The globulin concentration obtained in the current study was higher than the expected normal range of 27 to $41 \mathrm{~g} / \mathrm{L}$ [19]. The high globulin concentration coupled with low albumin obtained in the current study lead to the very low albumin: globulin (A:G) ratio [8]. Elevated concentration of globulin and low albumin is indicative of an animal's immune system fighting off infection [7]. Veterinary records from the current study showed few occurrences of health challenges which were: $8 \%$ bacterial infections, $6 \%$ foot rot, $8 \%$ orf (contagious echthyma) and $2 \%$ pneumonia that necessitated the use of injectable antibiotics, copper sulphate solution and or wound remedies. The clinical health cases were independent of grazing system or floor type except for foot rot in which the goats with affected feet were solely from earth floors. Although blood sampling was done from apparently healthy goats, sub-clinical cases of such health challenges could have increased globulin concentrations. The high globulin concentrations in tethered goats kept on earth floors coupled with smaller albumin lead to the low A:G ratio could imply that they were more vulnerable to infection than the herded goats. The combination of stress from tethering and fatigue from spending nights standing on muddy earth floors appears to have exacerbated their welfare. The goats in the current study showed an apparent preference to consume browse. It is thought that the browse species contained condensed tannins (CT) that interfered with their immunity. Solaiman et al [26] found decreased white blood cells and increased lymphocytes at elevated CT levels in goat diets which compromised their immunity. In the current study, it is postulated that similar mechanisms could have compromised the immunity level of the goats leading to the observed high globulin concentrations. Rumosa Gwaze et al [23] attributed high globulin values in their study to internal parasite infestations. However, goats in the current study went through a routine deworming schedule and are thought to have been adequately protected against internal parasites. The compromised immunity of goats in the current study appears to point at the consumption of tannin rich browse species and possibility of opportunistic infection in cases of foot rot, pneumonia and orf that were occasionally observed.

Body weights, body condition scores and estimated intake The ADG in weights and BCS were similar between grazing systems and floor types. The BCS were within the optimal range of the 1 to 5 scale [16]. The similarities in ADG and BCS suggest that the goats under the two grazing systems, despite having different restrictions to motion or dissimilar estimated levels of feed intake [10], had similar growth performance. Estimated nutrient intake figures showed that herded goats consumed more
DM, TP, TDN, Ca, P, Vitamin A, and Vitamin D. The expected advantage in daily gains from high intake by herded goats could have been lost in energy expended in unrestricted foraging motion. The observation also affirms reports by [5] that blood metabolites reflect nutrient status of the animal that is more sensitive than monitoring body weight gains and BCS. The concentrations of blood metabolites were able to show differences in nutrient status despite the ADG and BCS appearing similar. Animals can lose bioenergy more than what is visible through BCS, or body weights, hence the need to compare nutrient status by using blood metabolites. The observed optimum BCS [16] and ADG, in the current study, demonstrated that nutrient supply was at least able to cover requirements for maintenance and growth [3]. Although faecal egg counts were not done to monitor prevalence of helminths, the possibility of internal parasites that normally cause stunted growth [2] was minimised in the current study by routinely drenching the goats using anthelmintics in rotation as prophylaxis and to counter anthelmintic resistance.

\section{Carcass characteristics}

The estimation of age by dentition [27] was similar to the goats' actual ages. Chi- square test demonstrated that there was no relationship between grazing system and: fat or conformation. However, the weight related carcass characteristics obtained in the current study were better in herded than tethered goats in terms of higher DP, more CCW, less shrinkage loss. The DP is affected by factors that include slaughter weight, feed withdrawal period before slaughter, gut contents, breed, masculine and fatness [28]. Gut contents largely account for variations in DP, and up to $26 \%$ of the live weight is attributable to gut content [29]. However, in the current study, the goats were weighed after fasting thereby eliminating gut contents as a source of the observed difference in DP. The higher pre slaughter weights of herded goats could have contributed to the high DP. More masculine animals have a higher DP, heavier carcasses and more fat cover than smaller animals [29]. In addition, goats on diets with higher metabolizable energy have higher DP and carcass weights. The observation appears to be in agreement with the results obtained in the current study where herded goats which had higher glucose levels and tended to have higher DP and carcass weights. Herded goats accommodated on slatted floors commanded much higher DP than other treatments possibly due to higher intakes and adequate rest during penning.

The lower fat values obtained for the goats can be ascribed to possible influence of CT in browse species consumed by goats. Solaiman et al [26] found a linear decrease in the fat thickness with increase in the level of CT in diets of sheep. Diets with CT reduce the bio-hydrogenation of fats in the rumen [26] that lead to low fat cover on carcasses. Although low fat cover attracts health conscious consumers to take chevon [29] the consistently low fat cover on goat carcass observed in the current study exposed them to cold shortening, tough meat and risked their possible 
downgrading [29]. Further, lean carcasses are prone to high shrinkage loss during chilling [28]. In the current study, shrink loss (SL) \% was surprisingly low and similar between the two grazing systems. Usually goats have high SL \% that is ascribed to their low fat content.

The majority of the carcasses of both tethered and herded goats were flat on conformation. Carcass conformation is a critical subjective visual criterion that places economic value to carcasses [17]. However, carcass conformation only account for less than $10 \%$ of the variation observed in meat yield [17]. The flat carcasses observed in the current study were consistent with the low serum creatinine concentrations in both treatment groups. Damptey et al [3] indicated that high creatinine is associated with more muscle mass and the metabolite being higher in bigger animals. Rumosa Gwaze et al [23] also reported that more creatinine was found in mature animals that had more muscle compared to the young animals. It is possible that the diet consumed by the goats was limiting in available protein possibly due to the detrimental effects of tannins. Diets deficient in protein give rise to narrow or flat carcasses.

\section{IMPLICATIONS}

Herding improved the efficiency of utilisation of amino acids, reduced the risk of chronic infections and resulted in higher body weights, better carcass traits. Floor type had minimal influence on metabolite concentrations where earth floors only reduced efficiency of utilisation of protein. Combined tethering and housing of goats directly on earth floors caused double stress that encouraged chronic infections. Therefore, herding of goats and housing them on slatted floors improved body weights and enhanced their welfare. Further studies are recommended to establish actual intake levels, feeding behaviour and identify pathogens leading to chronic infections and high activity of CK.

\section{CONFLICT OF INTEREST}

We certify that there is no conflict of interest with any financial organization regarding the material discussed in the manuscript.

\section{ACKNOWLEDGMENTS}

The authors are grateful to the support and funding from the National Research Foundation (NRF, Collaborative Postgraduate Training UID: 92544) that covered laboratory analysis and study expenses. Sincere thanks go to Mr Bruce McMillan and East London Abattoir for slaughtering the goats. Gratitude is also extended to the Goat Research Assistants for the handling and care given to the study animals. The Agricultural Science Workshop team and University of Fort Hare Honeydale Research Farm Management and Staff are also thanked for assisting with the construction of the goat pens.

\section{REFERENCES}

1.Moniruzzaman M, Hashem MA, Akhters S, Hossain MM. Effect of different feeding systems on carcass and non-carcass parameters of Black Bengal goats. Asian-Australas J Anim Sci 2002;15:61-5.

2.Chikwanda AT, Mutisi C, Sibanda S, et al. The effect of housing and anthelmintic treatment on pre-weaning kid death rate and infestation with gastrointestinal helminthes. Appl Anim Husb Rural Dev 2013;6: 32- 5 .

3.Damptey JK, Obese FY, Aboagye GS, Ayim-Akonor M, Ayizanga RA. Blood metabolite concentrations and postpartum resumption of ovarian cyclicity in Sanga cows. S Afr J Anim Sci 2014;44:10-7.

4.Chimonyo M, Kusina NT, Hamudikuwanda H, Ncube I. Changes in stress related plasma metabolite concentrations in working Mashona cows on dietary supplementation. Livest Prod Sci 2002;73:165-73.

5.Olafadehan OA. Changes in haematological and biochemical diagnostic parameters of Red Sokoto goats fed tannin- rich. Pterocarpus erinaceus forage diets. Vet Arh 2011;81:471-83.

6.Pambu- Gollah R, Cronje PB, Casey NH. An evaluation of the use of blood metabolite concentrations as indicators of nutritional status in free ranging indigenous goats. S Afr J Anim Sci 2000;30:115-20.

7.Ndlovu T, Chimonyo M, Okoh AI, et al. A comparison of nutritionally related blood metabolites among Nguni, Bonsmara and Angus steers raised on sweet-veld. Vet J 2009;179:273-81.

8.Mapiye C, Chimonyo M, Dzama K, Marufu MC. Protein status of indigenous Nguni and crossbred cattle in the semi- arid rangelands in South Africa. Asian-Australas J Anim Sci 2010;23:213-25.

9.Acocks JPH. Veld types of South Africa. 3rd ed. Mem Bot Surv S Afr 1988;57:1-146.

10. National Research Council. Nutrient requirements of domestic animals. Nutrient requirements of goats: Angora and meat goats in temperate and tropical countries. 15th ed. Washington DC: National Academy Press; 1981.

11. Gochman N, Schmitz JM. Application of a new peroxidase indicator reaction to the specific, automated determination of glucose with glucose oxidase. Clin Chem 1972;18:943-50.

12. Tietz NW. Clinical guide to laboratory tests. 3rd ed. Philadelphia, PA: WB Saunders Co.; 1995.

13. Lowry OH, Rosebrough NJ, Farr AI, Randall RJ. Protein measurement with folin phenol reagent. J Biol Chem 1951;193:265-75.

14. Pinnell AE, Northam BE. New automated dye-binding methods for serum albumin determination with bromcresol purple. Clin Chem 1978;24:80-6.

15. Horder M, Elsr RC, Gerhardt W, Mathieu M, Sampson EJ. Approved recommendation on IFCC methods for the measurement of catalytic concentration of enzymes. Part 7, IFCC method for creatine kinase. Eur J Clin Chem Biochem 1991;29:435-56.

16. Koyuncu M, Altincetic SO. Importance of body condition score in dairy goats. Maced J Anim Sci 2013;3:167-73.

17. Sebsibe A, Casey NH, van Niekerk WA, Tegegne A, Coertze RJ. Growth performance and carcass characteristics of three ethiopian goat breeds fed grainless diets varying in concentrate to roughage ratios. S Afr J 
Anim Sci 2007;37:221-32.

18. SAS. Statistical analysis system user's guide. 5th ed. Version 6, Raleigh, NC: SAS Inst. Incl., 2003.

19. Kaneko JJ, Harvey JWM, Bruss L. Clinical biochemistry of domestic animals. 6th ed. Burlington, MA: Academic Press; 2008.

20. Vojtic I. Macro ck type 1 as a major component of serum creatine kinase activity in pregnant sheep. Small Rumin Res 2000;35:249-53.

21. Chulayo AY, Muchenje V. Effect of pre-slaughter conditions on physicochemical characteristics of mutton from sheep breeds slaughtered at a smallholder rural abattoir. S Afr J Anim Sci 2013;43:64-98.

22. Dieni CA, Storey KB. Creatine kinase regulation by reversible phosphorylation in frog muscle. Comp Biochem Physiol (Part B) 2009;152: 405-12.

23. Rumosa Gwaze F, Chimonyo M, Dzama K. Relationships between nutritionally- related blood metabolites and gastrointestinal parasites in nguni goats of South Africa. Asian-Australas J Anim Sci 2010;23: $1190-7$.
24. Nonaka I, Takusari N, Tajima K, et al. Effects of high environmental temperatures on physiological and nutritional status of pre-pubertal Holstein heifers. Livest Sci 2008;113:14-23.

25. Nuttall FQ, Gannon MC. Dietary protein and the blood glucose concentration. Diabetes 2013;62:1371-2.

26. Solaiman S, Thomas J, Dupre Y, et al. Haenlein effect of feeding Sericea Lespedeza (lespedeza cuneate) on growth performance, blood metabolites and carcass characteristics of Kiko crossbred male kids. Small Rumin Res 2010;93:149-56.

27. Soji Z, Chikwanda D, Chikwanda AT, et al. Relevance of the formal red meat classification to the South African informal livestock sector. S Afr J Anim Sci 2015;45:263-77.

28. Webb EC, Casey NH, Simela L. Goat meat quality. Small Rumin Res 2005;60:153-66.

29. Simela L, Webb EC, Bosman MJC. Live animal and carcass characteristics of South African indigenous goats. S Afr J Anim Sci 2011;41: $1-15$. 